\title{
Parasitism of Egeria radiata (Lamarck, 1804) in Lower Sanaga delta, Cameroon: Prevalence, Diversity, Intensity and its Impact on This Economic and Nutritional Clam Species
}

Adolphe DIKOUME ( $\nabla$ dikoumethierry@gmail.com )

University of Douala: Universite de Douala

Gordon AJONINA NWUTIH

University of Douala: Universite de Douala

Loick Pradel KOJOM FOKO

University of Douala: Universite de Douala

Minette TOMEDI EYANGO

University of Douala: Universite de Douala

\section{Research}

Keywords: Egeria radiata, clams, parasitology, lower Sanaga, Cameroon.

Posted Date: May 26th, 2021

DOI: https://doi.org/10.21203/rs.3.rs-511268/v1

License: (9) (1) This work is licensed under a Creative Commons Attribution 4.0 International License. Read Full License 


\section{Abstract}

Background: Clams are an important source of economic incomes and animal protein source in Cameroon. In contrast, parasitism is a serious threat to the economy and health risk to Cameroonian populations. The present study aimed at determine diversity and intensity of parasitism along with its impact on E. radiata, a major clam species in the country.

Methods: Parasitic screening of freshwater Egeria radiata was carried out December 2017 to July 2018 at lower Sanaga delta in the Littoral region of Cameroon. Bolounga and Maldjedou were local stations of sampling, where clams were collected and in situ measurements of weight, length and width and were transported to the laboratory for parasites survey. Parasites were examined and attempt was made on the identification using appropriate keys.

Results: Statistical analysis of results showed that the parasitic prevalence was $74.5 \%$ overall and was $56 \%$ and $90 \%$ at Bolounga and Maldjedou respectively. The prevalence of parasites habour found were Protozoans (10\% vs $0 \% ; p=0.01)$, Trematodes ( $4 \%$ vs $16.7 \% ; p=0.04)$, Cestodes ( $6 \%$ vs $23 \% ; p=0.01$ ) and Nematodes ( $12 \%$ vs $31.7 \% ; p=0.01$ ) at respectively Bolounga and Maldjedou stations. Parasites diversity of Egeria radiata show Intensity index at Bolounga and Maldjedou was respectively 1.35 and 1.31 with 1.32 overall. Abundance rate was 0.99 overall and was 0.76 and 1.18 at Bolounga and Maldjedou respectively. Significative correlation can be observed with Burrow and parasitic index; The size of clams in two stations show lengths (5.2mm vs $4.5 \mathrm{~mm}$ ), height $(4.1 \mathrm{~cm}$ vs $3.5 \mathrm{~cm})$, total shell weight $(38.9 \mathrm{~g}$ vs $30.0 \mathrm{~g})$ and left shell weight $(19.6 \mathrm{~g} \mathrm{vs} 15.2 \mathrm{~g})$. higher values were encountered in Maldjedou with significant differences that were observed.

Conclusion: Velocity of parasites inside bivalve species to burrow and filter water expose it to infection with these above mentioned groups of parasites that cause a mass mortality and significant economic losses and public health.

\section{Background}

Urbanization and demographic growth increasingly observed in developing countries, especially

inCameroon,have contributed to an increasing and urgent demand in proteins of animal origin [1]. In Cameroon, bivalve mollusks (i.e., clams) are exploited by a restricted local community fishing groups in the District of Mouanko (Littoral region) along the Sanaga Delta for their flesh and shell, with an estimated annual production of more than800 000 tons of clams [2]. Many Cameroonian authors expressed their fears regarding declining production of these palatable mollusk species in actual this context of increased demand of animal proteins.

Clams are greatly appreciated by Cameroonian populations for the quality of their wite flesh and secondary services produced by their shells notably as a source of calcium in poultry feed and in lime manufacturing [2; 3]. The exploitation of clams is an income-generating activity as it generates enormous profits for local communities through their employment along the Cross-River waters in Nigeria, Volta in Ghana, and Sanaga in Cameroon, and positivelyimpacts the economy of these three counties [4;5]. However, a set of biotic and abiotic factors including parasitism have contributing to decrease in clam populations, and as a consequence a decline in food production and financial resources over the course of the fishing season [2]. Parasitism is important in the process of regulating aquatic ecosystem invertebrate populations $[6 ; 7 ; 8]$. Unfortunately, parasitism has 
received little attentiondespite its impact inclam mortality and economic losses in the exploitation of edible species such as bivalves $[8 ; 9]$.

Egeria radiata (Lamarck, 1804) is one of the main bivalves exploited in Cameroon by local population. Previous studies in Ghana and Nigeria outlined that this clam species was highly vulnerable to contamination by diverse pathogens includingcoliform bacteria [5], and parasites (trematodes, cestodes, nematodes and protozoans)[10]. There is a lack of parasitological studies on E. radiata in Cameroon, especially in the Lower Sanaga river. The implementation of such study is a crucial prerequisite in an attempt to successfullydomesticate this clam species in the country. We therefore conducted a study to determinethe diversity and intensity of parasite fauna, and its impact on characteristics of $E$. radiate populations from the Lower Sanaga river.

\section{Methods}

\section{Study area}

The study took place from December 2017 to July 2018 in two sites of Mouanko area, namely Bolounga and Maldedjou. Mouanko is a district of the Division of Sanaga Maritime, Littoral region, Cameroon, located on the banks of the Sanaga River (Fig. 1) [2]. Its average geographical coordinates range from 3-38' north latitude, to 9-47' east longitude. The district of Mouanko has about 17,000 inhabitants. The majority of local populations live mainly from fishing and their activities are restricted to the vicinity of streams and alluvial forests. River fishing is mainly based on Cichlidae, catfish and clams.

\section{Study Design}

The $E$. radiataclams were collected at the study sites of interest with help of local fishermen. The fishermen were informed on the objectives of the study, and only those who gave their approval were included in the study for captures. The measurements (length, height, width and bulge) on each clam individualwere made on spot. Thereafter, the valves of each clam were opened, and different body parts were collected for identification of parasite diversity and intensity (Fig. 2).

\section{Collection and measurements ofE. radiatapopulations}

The clams were collected with the help of local fishermen along the study sites of the Sanaga river, and morphometricparameters (i.e., length, height, and bulge) were made on spot using a sliding foot to the nearest millimeter. The clams were then placed in individual plastic bags, brought to the Laboratory for further identification of parasitic organisms (Fig. 3).

\section{Identification Of The Parasites}

The identification of different parasite classes was made using published taxonomic identification keys [11; 12; 13; 14]. Different body parts (gills, foot, siphons, visceral mass and mantle) and soft body partof each $E$. radiataindividual were analyzed to identify different development stages of main parasite classes (trematodes, cestodes, nematodes and protozoans). Briefly, metazoans were identified by microscopic observation of the 
crushed sections of the above mentioned body parts. Biopsies of the E. radiata's soft body were made for the microscopic identification of endoparasites.

\section{Condition, Diversity And Ecological Indexes}

The analysis of parasite composition was made using several condition, parasitological and ecological indexes $[15 ; 16]$. Parasite communities were studied at the infrapopulation level (i.e., all members of a parasite species found in/on the host), and the different indexes were determined as follows $[17 ; 18 ; 19]$. :

- Elongation index (Ei) is the ratio between height and lengthof the clam. In practice, Ei is low when environmental conditions are favorable while high Ei values reflect unfavorable environmental conditions ;

- Condition index $(K)$ is calculated using the following formula $K=10^{4} \times\left(\mathrm{W} / \mathrm{L}^{3}\right)$ where $\mathrm{W}$ and $\mathrm{L}$ are weight and length of clam, respectively ;

- Parasite prevalence $(P)$ was defined as the ratio between the number of parasitized host individuals and the total number of host individuals;

- Parasite abundance (AM) was computed by dividing the number of parasite individuals found to the number of clams examined;

- Mean intensity of the parasitofauna (IM) was defined as the total number of a given parasite species divided by the total number of clams infected with this parasite species. IM was categorized as very low (<10), low $(10 \leq \mathrm{IM} \leq 50)$; moderate $(50<\mathrm{IM} \leq 100)$, and high $(\mathrm{IM}>100)$ as described.

- Parasite specific richness $(S)$ is the number of species found in each clam examined.

\section{Statistical analysis}

The data were keyed into an Excel spreadsheet, and then exported to the statistical package for social sciences v17 (SPSS, IBM, Inc., Chicago, USA) and GraphPad v5.03 (GraphPad PRISM, Inc., San Diego, USA) for statistical analysis. Qualitative variables were presented as percentages while quantitative variables were presentedas mean \pm standard deviation (SD). Non-parametric tests of Kruskal-Wallis and Mann-Whitney, and parametric unpaired sample Student tests were used to compare mean values. Pearson's independence chi-square and Fisher's exact tests were used to compare percentage values. Statistical significance was set at $p$-value less than 0.05 .

\section{Results And Discussion}

\section{Results}

\section{Characteristics of the clams collected in the study sites}

A total of 110 clams were collected during the study, 50 in Bolounga and 60 in Maldjedou. The comparative analysis of morphometric characteristics of clams between the study sites revealed that mean values of total shell weight, length and height of clams collected in Madjedou were significantly higher than those of their counterparts collected in Bolounga: $30.0 \pm 17.1$ vs $38.9 \pm 22.9, p=0.02$ (total shell weight, g), $4.5 \pm 1.2$ vs $5.2 \pm$ $1.4, p=0.005$ (length, $\mathrm{cm}$ ), and $3.5 \pm 0.8$ vs $4.1 \pm 0.8, p=0.001$ (height, $\mathrm{cm}$ ) (Table 1). 
Table 1

Morphometric characteristics of $E$. radiata clams by study sites

\begin{tabular}{|llll|}
\hline Parameters & Bolounga $(\mathrm{n}=\mathbf{5 0})$ & Maldjedou $(\mathrm{n}=\mathbf{6 0})$ & $\boldsymbol{p}$ \\
\hline Total shell weight $(\mathrm{g})$ & $30.0 \pm 17.1$ & $38.9 \pm 22.9$ & $0.02^{*}$ \\
\hline Left shell weight $(\mathrm{g})$ & $15.2 \pm 8.6$ & $19.6 \pm 11.5$ & $0.02^{*}$ \\
\hline Length $(\mathrm{cm})$ & $4.5 \pm 1.2$ & $5.2 \pm 1.4$ & $0.005^{*}$ \\
\hline Height $(\mathrm{cm})$ & $3.5 \pm 0.8$ & $4.1 \pm 0.8$ & $0.001^{*}$ \\
\hline Bulge $(\mathrm{cm})$ & $2.4 \pm 0.7$ & $2.6 \pm 0.5$ & 0.05 \\
\hline Data are presented as mean \pm SD & & \\
\hline
\end{tabular}

\section{Prevalence Of Infection}

Of the total number of clams collected, 82 carried at least one parasite species, giving an overall infection prevalence of $74.5 \%$ (95\% Cl 65.7-81.8\%). The infection prevalence was 56\% (95\% Cl 42.3-68.4\%) in Bolounga and $90 \%(95 \% \mathrm{Cl} 79.9-95.3 \%)$ in Maldjedou, and the difference was statistically significant $(p=0.0001)$.

\section{Prevalence Of The Different Parasites Classes By Study Sites}

The analysis of clams revealed different parasite groups including protozoans, cestodes, trematodes and nematodes. Protozoans were found only in Bolounga (10\%). The prevalence of cestodes, trematodes and nematodes was significantly higher in Maldjedou compared to Bolounga (e.g., $12.0 \%$ vs $31.7 \%, p=0.01$ for nematodes). It should be noted that nematodes were the main parasite classes found in both the study sites (Fig. 4).

\section{Elongation And Condition Indexes}

The elongation and condition indexes were higher in Bolounga compared to Maldjedou, but statistical difference was found only for condition index ( $p=0.0067)$ (Fig. 5).

\section{Parasitological And Ecological Indexes}


The parasite abundance was significantly lower in Bolounga as compared to Maldjedou $(p=0.0001)$ as depicted in Table 2. The same pattern was observed for specific richness, where a maximum of three parasite species were found in Bolounga. Parasite intensity rates were similar between the two sites $(p=0.841)$.

Table 2

Comparative analysis of indexes between the study sites

\begin{tabular}{|lllll|}
\hline Indexes & $\begin{array}{l}\text { All } \\
(\mathbf{n}=\mathbf{1 1 0})\end{array}$ & $\begin{array}{l}\text { Bolounga } \\
(\mathbf{n}=\mathbf{5 0})\end{array}$ & $\begin{array}{l}\text { Maldjedou } \\
(\mathbf{n}=\mathbf{6 0})\end{array}$ & $\boldsymbol{p}$ \\
\hline Prevalence, \% & 74.5 & 56.0 & 90.0 & $0.0001^{*}$ \\
\hline Abundance & 0.99 & 0.76 & 1.18 & $0.0001^{*}$ \\
\hline Intensity & 1.32 & 1.35 & 1.31 & 0.841 \\
\hline Specific richness (Range) & $0.6 \pm 0.5$ & $0.4 \pm 0.6$ & $0.7 \pm 0.5$ & $0.003^{*}$ \\
& $(0-3)$ & $(0-3)$ & $(0-2)$ & \\
\hline Data are presented as percentages, and mean \pm SD & & \\
\hline Pearson's independence chi-square and unpaired Student's tests were used to make comparisons \\
\hline
\end{tabular}

\section{Impact Of Parasitism On The Characteristics Of Clams}

No statistically significant difference was found for morphometric parameters between clams infected and uninfected with protozoans and trematodes.In contrast, the bulge of clams was significantly higher in those infected with cestodes and nematodes compared to their uninfected counterparts (Table 3). All morphometric parameters, with the exception of bulge, were significantly lower in clams infected with parasites of not specified class (Table 3). 
Table 3

Variation of morphometric characteristics with respect to infection by different parasite groups

\begin{tabular}{|c|c|c|c|c|c|c|c|c|c|}
\hline & Protozoa & & & Cestodes & & & Trematod & & \\
\hline Parameters & $\begin{array}{l}\text { Absence } \\
(n= \\
105)\end{array}$ & $\begin{array}{l}\text { Presence } \\
(n=105)\end{array}$ & $\mathrm{p}$ & $\begin{array}{l}\text { Absence } \\
(n=93)\end{array}$ & $\begin{array}{l}\text { Presence } \\
(n=17)\end{array}$ & $\mathrm{p}$ & $\begin{array}{l}\text { Absence } \\
(n=92)\end{array}$ & $\begin{array}{l}\text { Presence } \\
(\mathrm{n}=12)\end{array}$ & $\mathrm{p}$ \\
\hline $\begin{array}{l}\text { Total shell } \\
\text { weight }(\mathrm{g})\end{array}$ & $\begin{array}{l}35.2 \pm \\
21.2\end{array}$ & $\begin{array}{l}27.8 \pm \\
9.8\end{array}$ & 0.60 & $\begin{array}{l}33.3 \pm \\
19.8\end{array}$ & $\begin{array}{l}43.4 \pm \\
25.3\end{array}$ & 0.11 & $\begin{array}{l}34.9 \pm \\
20.9\end{array}$ & $\begin{array}{l}34.6 \pm \\
21.5\end{array}$ & 0.92 \\
\hline $\begin{array}{l}\text { Left shell } \\
\text { weight }(\mathrm{g})\end{array}$ & $\begin{array}{l}17.8 \pm \\
10.6\end{array}$ & $\begin{array}{l}14.0 \pm \\
5.0\end{array}$ & 0.53 & $\begin{array}{l}16.8 \pm \\
9,9\end{array}$ & $\begin{array}{l}22.0 \pm \\
12.8\end{array}$ & 0.10 & $\begin{array}{l}17.6 \pm \\
10.5\end{array}$ & $\begin{array}{l}17.5 \pm \\
10.9\end{array}$ & 0.82 \\
\hline $\begin{array}{l}\text { Length } \\
(\mathrm{cm})\end{array}$ & $4.9 \pm 1.3$ & $4.5 \pm 0.7$ & 0.56 & $4.8 \pm 1.3$ & $5.5 \pm 1.5$ & 0.08 & $4.9 \pm 1.3$ & $5.0 \pm 1.4$ & 0.90 \\
\hline $\begin{array}{l}\text { Height } \\
(\mathrm{cm})\end{array}$ & $3.8 \pm 0.9$ & $3.6 \pm 0.5$ & 0.74 & $3.8 \pm 0.8$ & $4.2 \pm 1.0$ & 0.07 & $3.8 \pm 0.8$ & $3.9 \pm 0.9$ & 0.81 \\
\hline Bulge (cm) & $2.5 \pm 0.6$ & $2.5 \pm 0.3$ & 0.71 & $2.5 \pm 0.6$ & $2.6 \pm 0.8$ & $0.02^{\star}$ & $2.5 \pm 0.7$ & $2.5 \pm 0.4$ & 0.86 \\
\hline
\end{tabular}

Table 3

Variation of morphometric characteristics with respect to infection by different parasite groups (continued and end)

\begin{tabular}{|c|c|c|c|c|c|c|}
\hline & Nematodes & & & Not specifie & & \\
\hline Parameters & $\begin{array}{l}\text { Absence } \\
(n=85)\end{array}$ & $\begin{array}{l}\text { Presence } \\
(n=25)\end{array}$ & $\mathrm{p}$ & $\begin{array}{l}\text { Absence } \\
(n=86)\end{array}$ & $\begin{array}{l}\text { Presence } \\
(n=24)\end{array}$ & $\mathrm{p}$ \\
\hline Total shell weight (g) & $34.4 \pm 19.6$ & $36.5 \pm 25.3$ & 0.51 & $36.4 \pm 21.3$ & $29.4 \pm 18.9$ & 0.05 \\
\hline Left shell weight (g) & $17.4 \pm 9.8$ & $18.3 \pm 12.7$ & 0.57 & $18.4 \pm 10.7$ & $14.7 \pm 9.4$ & $0.03^{*}$ \\
\hline Length (cm) & $4.9 \pm 1.2$ & $5.0 \pm 1.6$ & 0.29 & $5.0 \pm 1.3$ & $4.5 \pm 1.2$ & $0.007^{*}$ \\
\hline Height (cm) & $3.8 \pm 0.8$ & $3.9 \pm 1.0$ & 0.49 & $3.9 \pm 0.9$ & $3.5 \pm 0.7$ & $0.01^{*}$ \\
\hline Bulge $(\mathrm{cm})$ & $2.4 \pm 0.5$ & $2.8 \pm 1.0$ & $0.01 *$ & $2.6 \pm 0.7$ & $2.4 \pm 0.4$ & 0.14 \\
\hline \multicolumn{7}{|c|}{ Data are presented as mean \pm SD } \\
\hline \multicolumn{7}{|c|}{ Mann-Whitney test was used to compare mean values } \\
\hline *Statistically signific & at $p<0.05$ & & & & & \\
\hline
\end{tabular}

We compared the morphometric characteristics of the $E$. radiata populations with respect to the specific richness (Table 4).Only width was significantly lower in clams infected with two parasite species compared to clams infected with one parasite species. 
Table 4

Impact of parasite species richness on E. radiata morphometric characteristics

\begin{tabular}{|llllll|}
\hline Parameters & $\begin{array}{l}\mathbf{S}=\mathbf{0} \\
(\mathbf{n}=\mathbf{4 9})\end{array}$ & $\begin{array}{l}\mathbf{S = 1} \\
(\mathbf{n}=\mathbf{5 7})\end{array}$ & $\begin{array}{l}\mathbf{S} \geq \mathbf{2} \\
(\mathbf{n}=\mathbf{4})\end{array}$ & $\mathbf{P}$ \\
\hline Total shell weight $(\mathrm{g})$ & $33.7 \pm 17.8$ & $36.1 \pm 23.1$ & $30.7 \pm 27.9$ & 1.298 & 0.52 \\
\hline Left shell weight $(\mathrm{g})$ & $17.1 \pm 8.8$ & $18.2 \pm 11.6$ & $15.5 \pm 14.5$ & 1.221 & 0.54 \\
\hline Length $(\mathrm{cm})$ & $4.8 \pm 1.2$ & $5.0 \pm 1.4$ & $4.7 \pm 1.9$ & 1.512 & 0.46 \\
\hline Height $(\mathrm{cm})$ & $3.7 \pm 0.7$ & $3.9 \pm 0.9$ & $3.7 \pm 1.1$ & 2.726 & 0.25 \\
\hline Bulge $(\mathrm{cm})$ & $2.4 \pm 0.4$ & $2.7 \pm 0.8$ & $2.4 \pm 0.4$ & 11.219 & $0.003^{*}$ \\
\hline Data are presented as mean \pm SD & & & & \\
\hline Kruskal-Wallis test was used to compare mean values & & \\
\hline *Statistically significant at $p<0.05$ & & & & \\
\hline
\end{tabular}

\section{Discussion}

Clams are an important source of economic incomes and animal protein source for population of sub-Saharan Africa countries, especially in Cameroon. Unfortunately, parasitism is a serious threat to the economy and health risk to these populations. The present study aimed at determine parasite diversity and intensity as well as the impact of this parasitism on E. radiata populations in the Lower Sanaga river, Cameroon.

All main groups of parasites (i.e., protozoans, trematodes, cestodes and nematodes) were found in this study, and this is consistent with works of Adeyemo et al.[10] who reported the same groups of parasites in the Nun River in Nigeria. The natural capacity of this bivalve species to burrow and filter water expose it to infection with these above mentioned groups of parasites which also live in the aquatic environment of E. radiata clam. In general, clams are victims of a large number of parasites that cause a mass mortality and significant economic losses $[7 ; 8 ; 9]$. Marine bivalves are often served as a host of metazoan parasites or symbiosis such as trematode, cestode, nematode and copepode. Such metazoans have been identified from various marine bivalves including oysters, mussels, cockles and clams [20; 21]. Several authors have reported on the occurrence of trematode and cestode in clams in Jeju Korea and Ariake Bay, Japan [22; 23]. .

The parasitofauna is mainly dominated by nematodes while protozoans were found with the lowest prevalence. This pattern is in line with that of Adeyemo et al. [10]. In addition, a significant difference was found in prevalence of the groups of parasites between the two study sites. This discrepancy is likely the fact of a geographic area-specificdistribution of the groups of parasites. The environment conditions are well known shape the distribution of numerous living organisms including parasites. High number of trematodes may affect reproductive processes and possibly retarding gonadal development [24]. The authors found that mite and trematode abundance were greater in smaller freshwater mussels [25].

Values of parasitological clues at Egeria radiata (Lamarck, 1804) 
Depending on the area, there was a higher average specific wealth in Maldjedou $(0.75 \pm 0.51)$ than in Bolounga significantly ( $\mathrm{p}-0.0033)$. That parasite indexes were higher for larger clams and could be explained by higher filtration rates. Furthermore could be explained also by longer exposure to infective particles [26]. In the present study, although clam shell length was $5.2 \pm 1.4 \mathrm{~cm}$ on average at Maldjedou compare to $4.5 \pm 1.2 \mathrm{~cm}$ at Bolounga. However, the maximum value of 3 was obtained for the entire population, as well as in Bolounga. This could be explained by the fact that in Bolounga the parasitic species here would have been more diverse than in Maldjedou and thus being a filterer more bioaccumulated of parasitic species. This result is lower than that of Adeyemo et al. [10] having found a value of 4 in the same host Galatea paradoxa (Born, 1778). The study showed a higher average specific richness associated with Bulging significantly ( $p-0.0035)$. The specific richness in relation to the morphometric parameters depending on the zones, revealed that the Bulging of clams in Bolounga would be the only parameter related to the specific parasitic richness. This could be explained by the fact that according to authors [10] molluscs are bioaccumulators that concentrate many parasitic species present in the water all around it. Acquisition of parasite infective stages can be increased for larger bivalves with high filtration capacities.

Parasite Intensity and Abundance

The overall prevalence of infection was $74.5 \%$. This value is higher than the $50 \%$ threshold used to identify the presence of dominant species according to authors [17].Similar prevalence values were reported in Nigeria [10]. This high value of infection burden could be due to anthropic activity as riverside residents used to dump wastes of varied nature, and parasitized feces, and thus contribute to the contamination of the aquatic milieu of $E$. radiata. As above stated, clams are important filterer organisms, and as a consequence are exposed to infection when filtering parasitized water. Parasite indexes were below 10 in the study sites, thereby implying that majority of parasite species have a very low mean intensity of infection [19]. A similar result was reported in Nigeria, where the authors found abundance values of 1 and 1.09 in their study sites [10]. Also prevalence and infection intensities of parasites at Bolounga were comparatively lower than the prevalence and intensities reported from Maldjedou, suggesting that overall health condition of Bolounga E. radiata clams was graded to be good.

Existing relationship between some biotic parameters of bivalve and Egeria radiata parasitolofauna.

Regarding the influence of parasitofauna on metric parameters, only the Bulge was influenced for clams parasitized at Cestodes ( $\mathrm{p}-0.028)$ and parasitized to nematodes ( $\mathrm{p}-0.017)$. This can be explained by the fact that helminths in general and especially these two classes contain endoparasites and mesoparasites that would have a direct influence on the weight of the soft body of the bivalve. Therefore, an influence of pathology on the metric parameters of the clam [27] to the example of the Egeria radiata Bulge. Parasite prevalence was higher in adults than in juveniles and could be explained by higher filtration rates and also by longer exposure to infective particles [26]. Condition index at Maldjedou show that despite low infection intensity an overall infection, Bolounga have better condition with $E$. radiata bivalves. The low infection intensity at two stations could be associated with a low density of clam and this index is positively correlated with the density of host organisms and environmental factors such substrate of area as bed [9;28].

However, including the group of parasites of unidentified species, significant associations were observed with metric parameters such as the weight of the left shell ( $p-0.036)$, the length of the shell ( $p-0.007)$, and the height of the shell (p-0.018). This can only be explained after extensive study on the identity of unidentified parasites. 


\section{Conclusion}

From this study determining parasitofauna in Egeria radiata (Lamarck, 1804), it should be remembered that: Regarding the characterization of clam parasitofauna, Egeria radiata (Lamarck, 1804) being a burrowing and filtering bivalve mollusc, has shown the ability to host an important parasitofauna. Thus the classes of Protozoans, Trematodes, Cestodes and Nematodes were met, with a domination of the Nematodes in both sampling sites. The parasitological indices showed a high parasitic prevalence and richness of $74.5 \%$ and 3 respectively for clams with $90 \%$ prevalence in the Maldjedou site. However, low values of abundance and parasitic intensity. The Bulge showed interest among the metric parameters, is positively correlated with prevalence and parasitic intensity in Egeria radiata on the basis of the results obtained. Only Bulge has been significantly associated with clams parasitized with Cestodes ( $\mathrm{p}-0.028)$ and parasitized with Nematodes ( $p$ 0.017). The domestication of these bivalves should take into account these results of the influence of parasitological diversity.

\section{Declarations}

\section{Ethics approval and consent to participate}

Not applicable Ethics approval and consent to participate. The data and other materials that support the findings of this study are available from the corresponding author upon reasonable request.

\section{Consent for publication}

Authors give consent for publication after each contribution. All authors read and approved the final manuscript freely.

\section{Availability of data and material}

The availability of data and material remains guaranteed by the corresponding author for any future solicitation

\section{Competing interests}

Authors have not declared any conflict of interests during each step of reading and may have influenced the study.

\section{Funding}

We extend our sincere gratitude to the Wildlife Conservation Society (CWCS) and staff in Mouanko based office that facilitated logistics and the measurements of the various parameters on the field.

We also thank Department of Botanic, University of Douala, Cameroon and all our free key informant and guides.

The population and fishermen gave us their freely assistance and warmth hospitality during the study especially his Bilvalve Collection Group.

Adolphe DIKOUME from the University of Douala designed the study, conducted the experiments, and wrote the manuscript. Gordon AJONINA from the University of Douala and CWCS conducted the experiments, did freely 
statistical analyses. KOJOM FOKO Loïck Pradel from University of Douala performed the data analysis. Minette TOMEDI EYANGO from the University of Doula designed freely the study.

\section{Authors' contributions}

AD designed the study, conducted the experiments, and wrote the manuscript. GA conducted the experiments, did statistical analyses. KFLP helped in write-up, statistical analysis and critically revised the manuscript for intellectual content. MTE designed the study. All authors read and approved the final manuscript.

\section{Acknowledgement}

We extend our sincere gratitude to the Wildlife Conservation Society (CWCS) and staff in Mouanko based office. We also thank The population of Mouanko and the Fishermen during the study especially Mr Samuel Engolo and his Bilvalve Collection Group.

\section{References}

1. -FAO. Situation mondiale des pêches et de l'aquaculture 2012. Organisation des Nations Unies pour I'Alimentation et l'Agriculture. Rome. 2012. 224p.

2. -Ajonina PU, Ajonina GN, Jin Mekongo E, Ayissi F, Usongo L. Gender roles and economics of exploitation, processing and marketing of bivalves and impacts on forest ressources in the Douala-Edea Wildlife reserve, Cameroun. International journal of Sustainable development World Ecology. 2005;12:161-72.

3. -Adjei-Boateng D, Wilson JG. Population dynamics of the freshwater clam Galatea paradoxa from the Volta River, Ghana. Knowledge Management of Aquatic Ecosystems. 2012;405:09-12.

4. -Etim L, Brey T. Growth, productivity, and significance for fishery of the bivalve Egeria radiata (Donacidae) in the Cross River, Nigeria. Archive of Fishery Marine Research. 1994;42:63-75.

5. -Adjei-Boateng D, Amisah S, Quagrainie KK. Bacteriological contamination of the freshwater clam (Galatea paradoxa) from the Volta estuary, Ghana. African Journal of Microbiological Research. 2009;3(7):396-9.

6. -De Montaudouin X, Kisielewski I, Bachelet G, Desclaux C. A census of macroparasites in an intertidal bivalve community, Arcachon Bay, France. Oceanol Acta. 2000;23:453-68.

7. -Desclaux C. Interactions hôtes-parasites: diversité, mécanismes d'infestation et impact des trématodes digènes sur les coques Cerastoderma edule (mollusque bivalve) en milieu lagunaire macrotidal. Thèse de Doctorat, Université Bordeaux I. 2003. 253p.

8. Géraldine -Lassalle, Montaudouin XD, Soudant P, Paillard C. Parasite co-infection of two sympatric bivalves, the Manila clam (Ruditapes philippinarum) and the cockle (Cerastoderma edule) along a latitudinal gradient. Aquatic Living Resources EDP Sciences. 2007;20:33-42. 75p.

9. -Paillard C. A short-review of brown ring disease, a vibriosis affecting clams, Ruditapes philippinarum and Ruditapes decussatus. Aquat Living Resour. 2004;17:467-75.

10. Oluseye -AdeyemoA, Goodluck O, Iniobong I. Parasitic survey of clam (Galatea paradoxa) from two locations in southern ljaw Local Government Area of Bayelsa State Nigeria. Merit Res J Environ Sci Toxicol. 2013;1(3):066-70.

11. -LomJ. and Dykova I. Myxozoan genera: definition and notes on taxonomy, life-cycle terminology and pathogenic species. Folia Parasitologica. 2006;53:1-36. 
12. -Bruno DW, Nowak B, Elliott DG. Guide to the identification of fish protozoan and metazoan parasites in stained tissue sections. Diseases of Aquatic Organisms. 2006;70:1-36.

13. -Gillet P, Potters I, et Jacobs J. Notes pratiques de Parasitologie Humaine Tropicale. Institut de Médecine Tropicale Prince Léopold. National straat. 2008. 155p.

14. - Centers for Diseases Control and prevention/ CDC Reports 1 in 6 Get Sick from Foodborne IIInesses Each Year/http://cdc.gov/foodborneburden/Visit at 19 December 2010, 5pm.

15. -Margolis LG, Esch W, Holmes JC, Kuris AM, Schad GA. The use of ecological terms in parasitology (report of an ad hoc committee of the American Society of Parasitologists). J Parasitol. 1982;68:131-3.

16. -Bush AO, Kevin DL, Jeffrey ML, Allen WS. Parasitology meets ecology on its own terms. J Parasitol. 1997;83:575-83.

17. -Watanabe S, Katayama S. Relationships among shell shape, shell growth rate, and nutritional condition in the manila clam (ruditapes philippinarum) in japan. Journal of Shellfish Research. 2010;29(2):8.

18. -Lucas A, Seninger PG. The use of physiological condition indices in marine bivalve aquaculture. Aquaculture.1985. 44: 187-200.

19. -Bilong-Bilong CF, et Njiné T. Dynamique de populations de trois monogènes parasites d'Hemichromis fasciatus (Peters) dans le lac municipal de Yaoundé et intérêt possible en pisciculture intensive. Sci Natet Vie. 1998;34:295-303.

20. -da Silva PM, Magalhaes ARM, Barracco MA. Effects of Bucephalus sp. (Trematodea: Bucephalidae) on Perna perna mussels from a culture station in Ratones Grande Island, Brazile. J Invt Pathol. 2002;79:15462.

21. -Gargouri Ben Abdallah L, Trigui El Menif N, Maaouri F. The morphology and behaviour of Cercaria lata Lespés, 1857 (Digenea, Faustulidae) from the Mediterranean clam Tapes decussata (L.). J Heminthol. 2009;83:69-76.

22. -Ngo TTT, Choi KS. Seasonal changes of Perkinsus and Cercaria infections in the Manila clam Ruditapes philippinarum from Jeju, Korea. Aquaculture. 2004;239:57-68.

23. -Park KI, Tsutsumi H, Hong JS, Choi KS. Pathology survey of the short-neck clam Ruditapes philippinarum occurring on sandy tidal flats along the coast of Ariake Bay, Kyushu, Japan. J Invert Pathol. 2008;99:212-9.

24. -Duangduen K, Sirilak C, Namfon P, Napatsorn N, Wivitchuta D. Buchephalid (Gasterostome) Cercariae obtained from Freshwater Clam in Thailand. J Tropical Med Parasitol. 2008;36:70-6.

25. -Gangloff MM, Lenertz KK, Feminella JW. Parasitic mite and trematode abundance are associated with reduced reproductive output and physiological condition of freshwater mussels. Hydrobiologia. 2008;610:25-31.

26. -Villalba AK, Reece K, Ordas MC, Casas SM, Figueras A. Perkinsosis in mollusks: a review. Aquat Living Resour. 2004;17:411-32.

27. -Dang C. Dynamique des populations de palourdes japonaises (Ruditapes philippinarum) dans le bassin d'arcachon conséquences sur la gestion des populations exploitées. L'université BORDEAUX 1. Ecole Doctorale Sciences et Environnements. 2009. 374p.

28. -Thao TT, Ngo, Choi K-S. Seasonal changes of Perkinsus and Cercaria infections in the Manila clam Ruditapes philippinarum from Jeju, Korea. Aquaculture. 2004;239:57-68. 

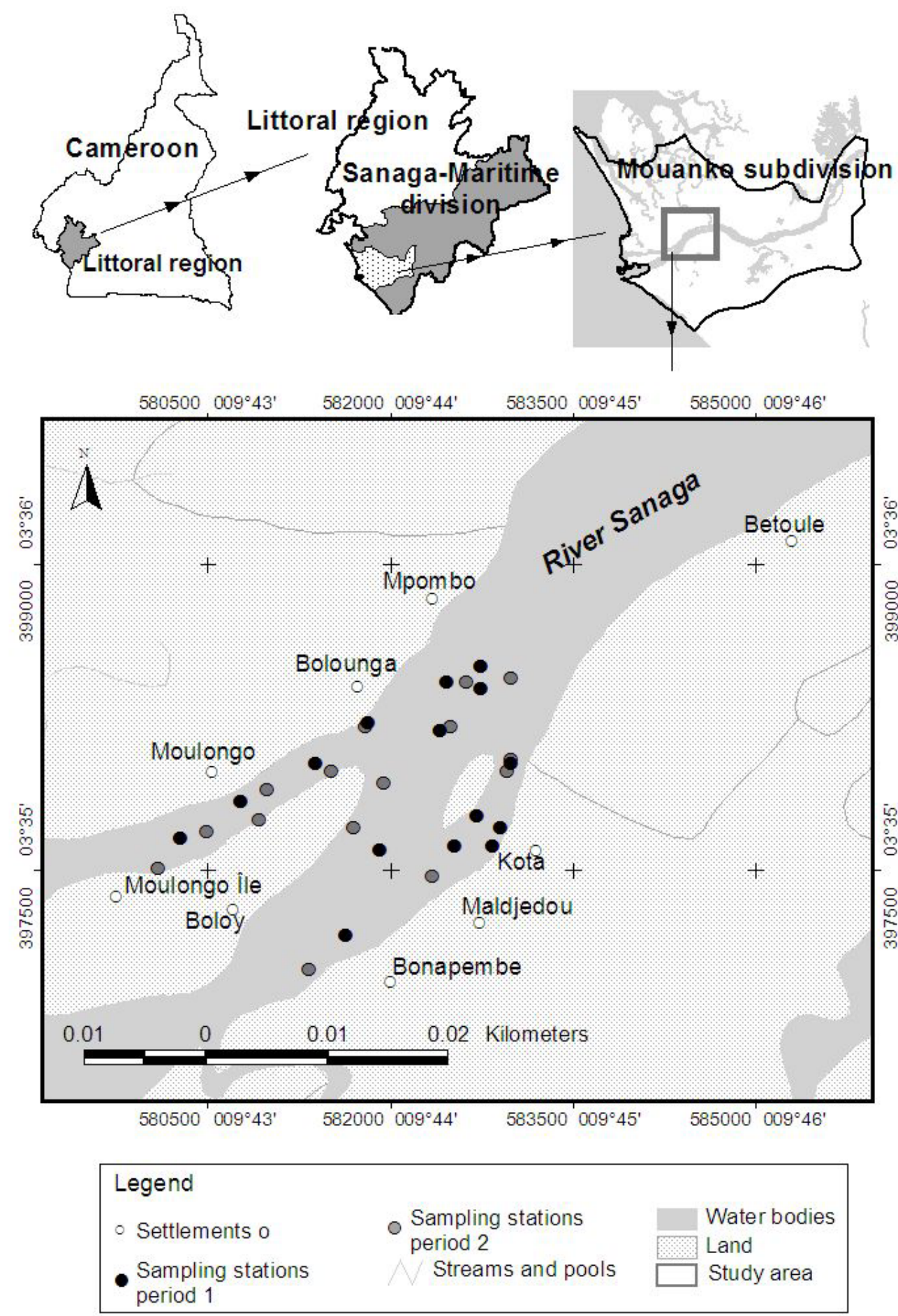

\section{Figure 1}

Map showing the Egeria radiata clam sampling location between sites in lower Note: The designations employed and the presentation of the material on this map do not imply the expression of any opinion whatsoever on the part of Research Square concerning the legal status of any country, territory, city or area or of its authorities, or concerning the delimitation of its frontiers or boundaries. This map has been provided by the authors. 


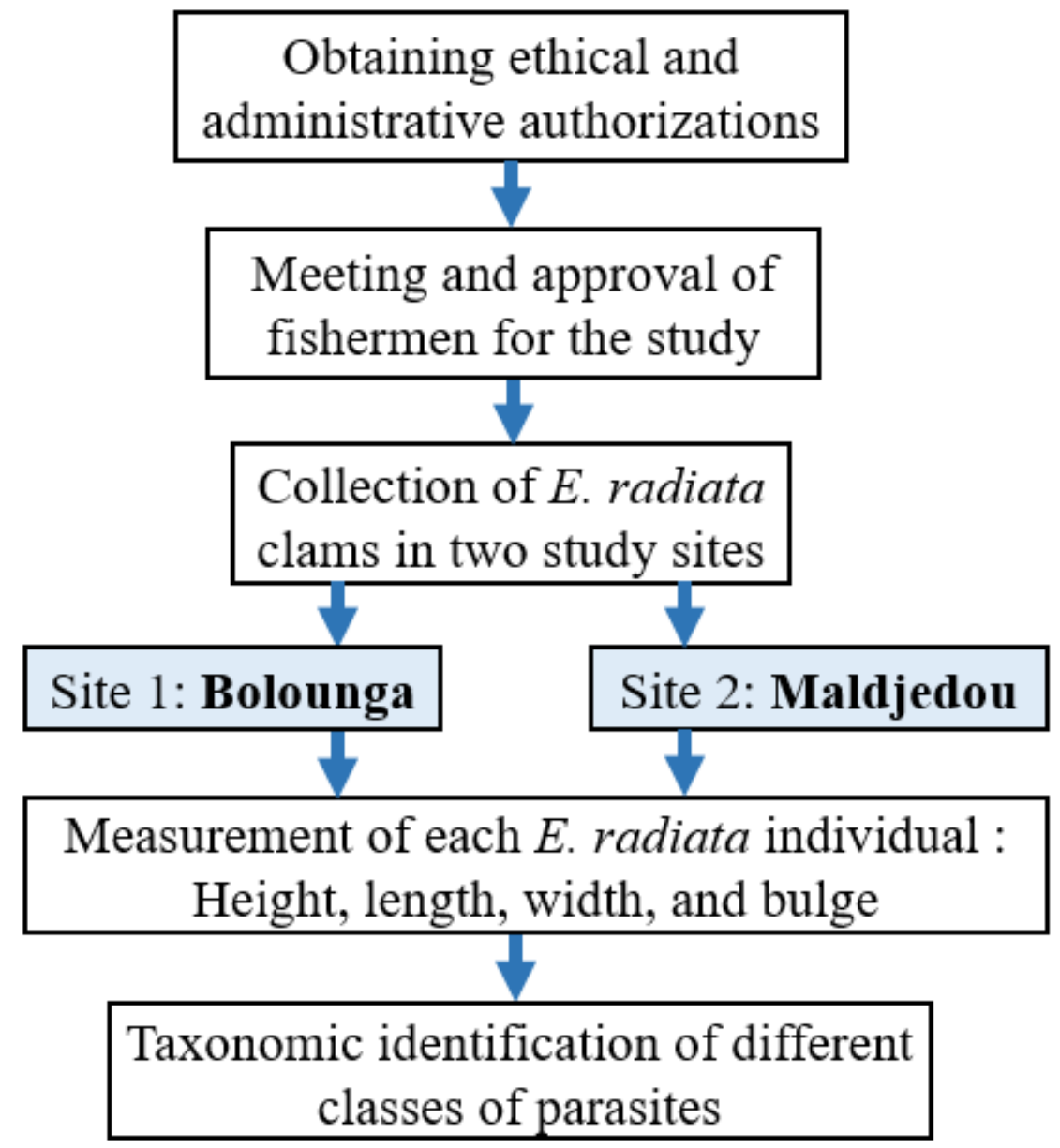

Figure 2

Flow diagram of the parasitological study on E. radiata in the Sanaga river 


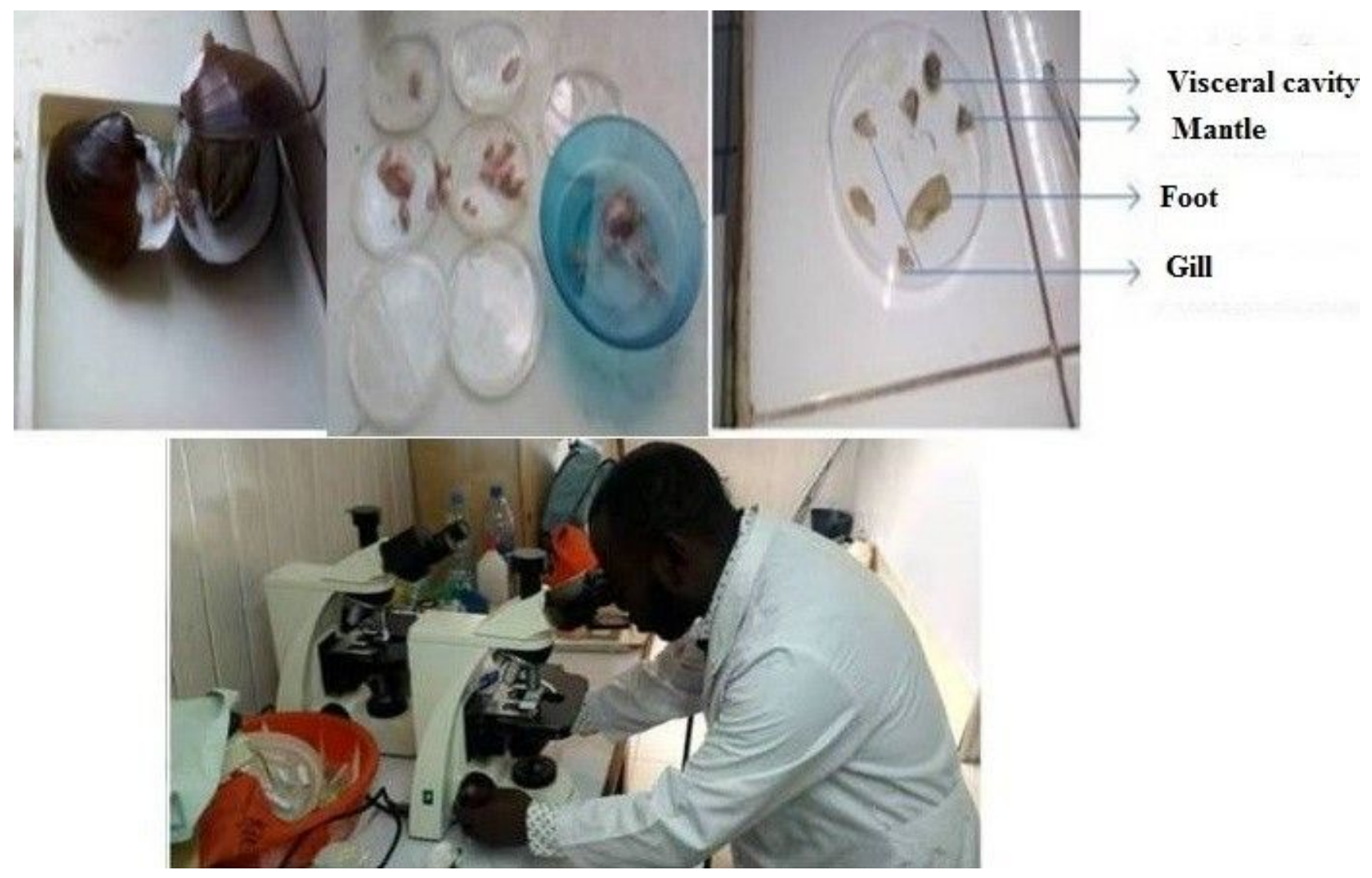

Figure 3

Organ harvesting of Egeria radiata (Lamarck, 1804) and parasitological screening

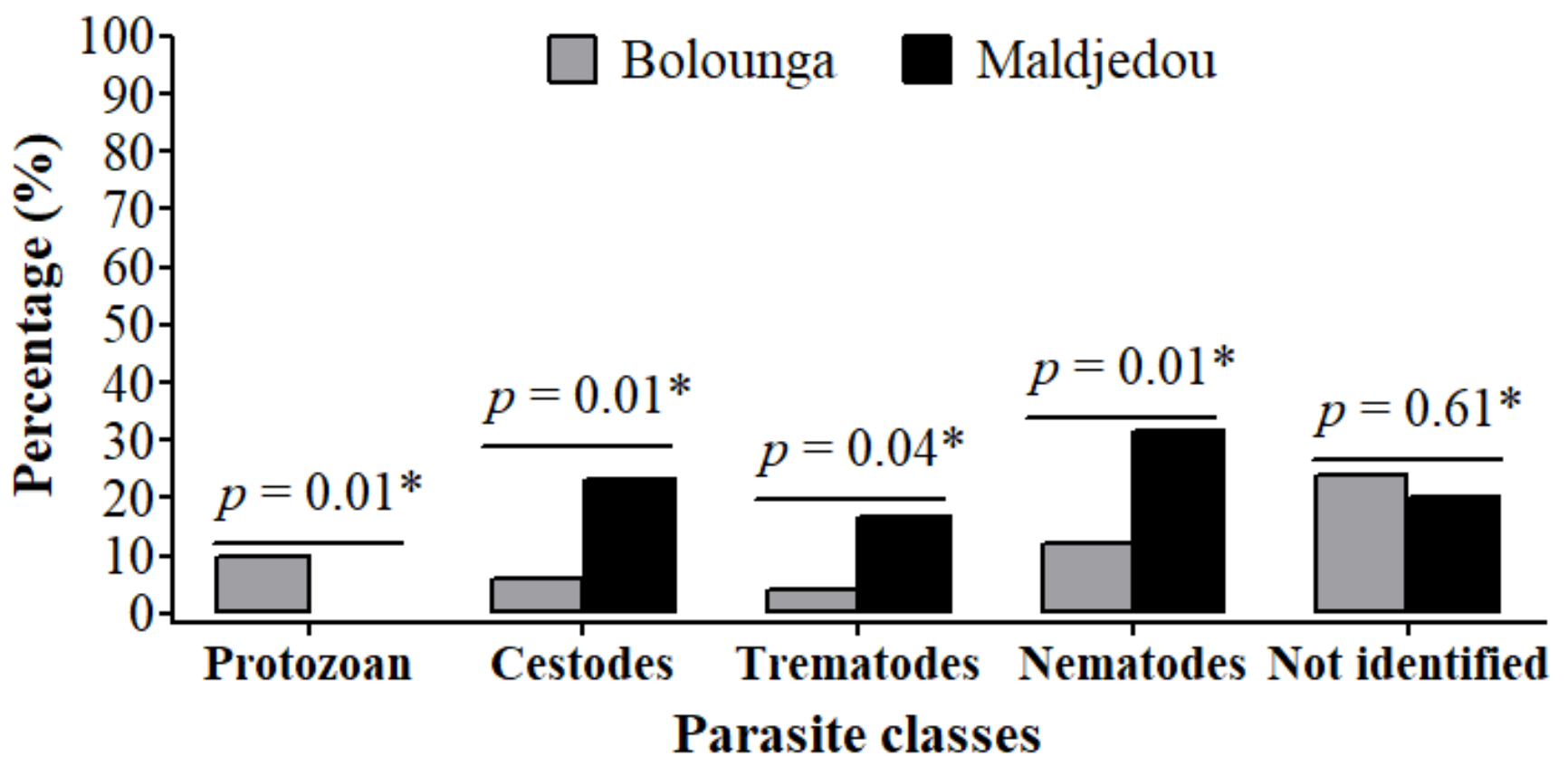

Figure 4

Prevalence of different parasite classes with respect to the study site Data are presented as percentages Pearson's independence chi-square test was used to compare percentages *Statistically significant at $p<0.05$ 

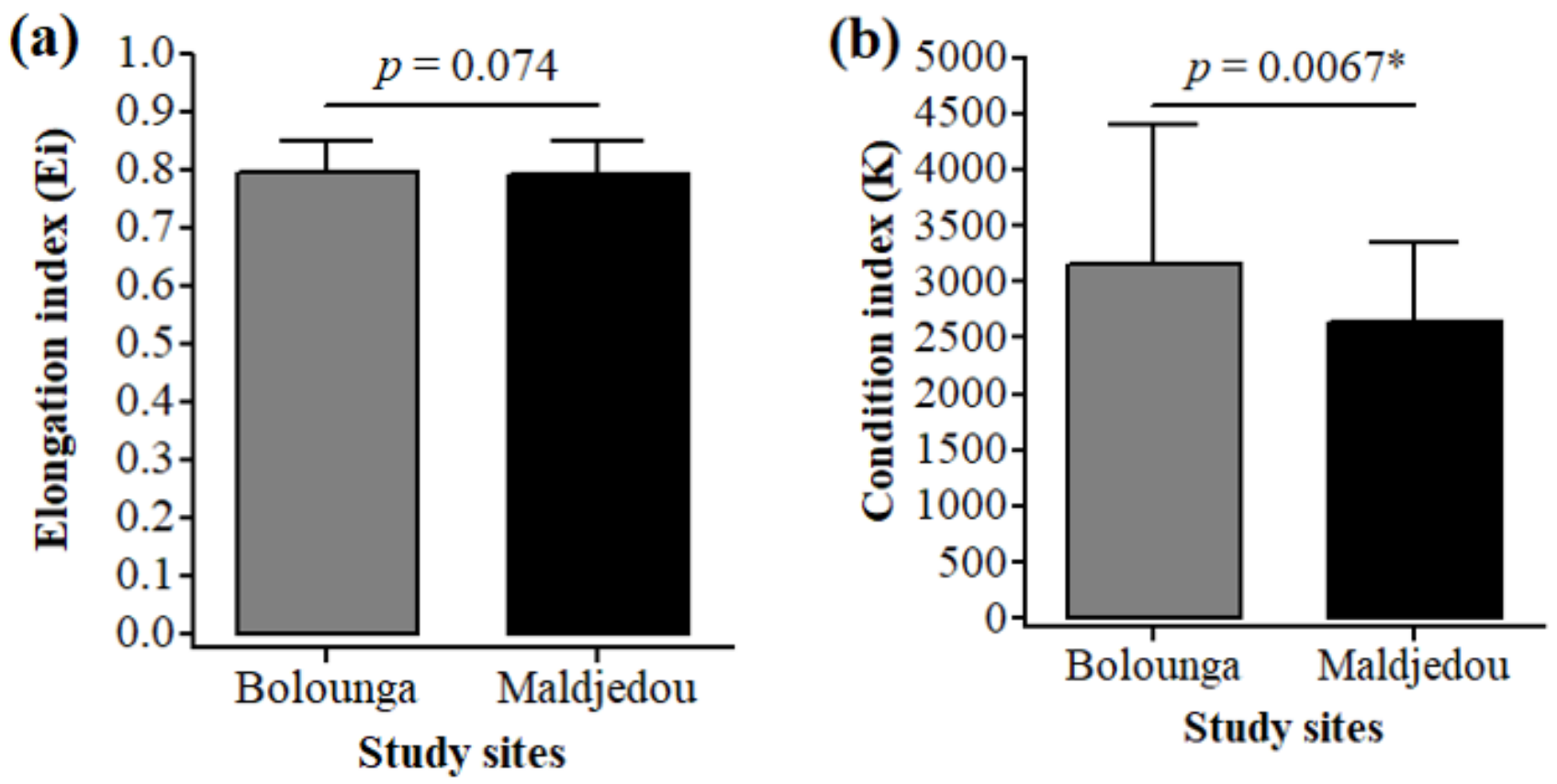

Figure 5

Variation elongation (a) and condition (b) indexes with respect to study area Bars represent as mean \pm SD Unpaired Student test was used to compare mean values *Statistically significant at $p<0.05$ 